\title{
På krykker over isen - hvorfor fritt valg ikke er løsningen på helsekøene
}

\author{
Hvor effektivt er egentlig fritt behandlingsvalg for å forkorte ventetidene ved norske sykehus?
}

Helseministeren har fremhevet fritt behandlingsvalg som ett av de viktigste tiltakene for å få unna helsekøene (1). Nylig fikk jeg anledning til å vurdere dette ved personlig erfaring og med referanse til 20 år i Skottland, der planstyrt integrasjon fremfor helsemarked og konkurranseutsetting er offentlig politikk. Fritt sykehusvalg er derfor mindre relevant.

\section{Raskt, effektivt høykvalitetstilbud}

Høsten 2015 gikk jeg til min fastlege for å få en henvisning til operasjon av hallux valgus. Svaret jeg fikk for henvisning til ortopedisk avdeling ved mitt nærmeste offentlige sykehus, var langt og inneholdt referanser til mye lovverk: Siden jeg ikke ble vurdert som en «prioritet under Pasientrettighetsloven» var min ventetid for vurdering minst fem år, les: evig. Jeg skiftet fastlege.

Min nye lege henviste meg til en privat aktør med kontrakt med helseforetaket, og time fulgte lynraskt, muligens fordi henvisningen ble gjort under Raskere tilbake-ordningen. Ting fortsatte i samme velkomne fart. Én måned senere gikk jeg inn på operasjonsstuen kl. 1130. Klokken 1500 samme dag satt jeg hjemme i sofaen og spiste sjokoladekake.

\section{System basert på egenressurser}

De neste to månedene på krykker, boende $i$ en blokk uten heis og med vinterglatte fortau utenfor, lærte meg dette om fritt valg av tjenester: Selv om tilbudet var effektivt for meg, er det ikke nødvendigvis samfunnsmessig effektivt, siden ikke alle har ressurser til å nyttiggjøre seg det.

Den første natten etter operasjonen måtte jeg sørge for at noen var hos meg. «Hva om jeg hadde vært alene», spurte jeg sykepleieren som velvillig fôret meg med kaffe og kjeks for å hjelpe meg ut av narkosen. «Da ville de ikke kunne ha gitt deg et tilbud», var svaret hennes. Vel hjemme lurte jeg på hvem som hadde ansvaret for meg hvis noe gikk galt $i$ et stengt Norge over juleferien? Den private virksomheten var stengt. Kirurgen var dratt på ferie, og selv om jeg hadde et telefonnummer, hadde jeg ingen opplysninger om hva hun kunne gjøre $i$ et krisetilfelle. Fastlegekontoret hadde ferieopplegg. Et «føre-var»-Google-søk fortalte om fire timers ventetid ved oppmøte uten time på legevakten, at de ikke hadde journaler fra andre tjenester, og at jeg ble anbefalt å ordne med relevante papirer selv. Da var det en fordel at jeg var i god form og hadde støtte hjemme.

Systemet som mitt flotte tilbud var en del av, syntes med ett lite brukervennlig. Jeg lengtet tilbake til Skottland. Der hadde min fastlege hatt ansvaret for oppfølging etter utskriving, også i ferietid. Ved akutt krise ville et medlem av et utvidet helseteam ha hjulpet med råd og informasjon, og om nødvendig ordnet med innleggelse og ambulanse.

\section{«Tjenestene er minst tilgjengelig for dem som trenger det mest»}

Utenom fastlegekontortid (0800-1800) er akuttjenesten samordnet med fastlege. En telefon setter pasienten over til en vakthavende som kan finne pasientjournalen elektronisk. Innleggelse kan ordnes uten oppmøte.

Tiden kom for tomånederskontroll. Jeg måtte ha med røntgenbilder fra et privat institutt - en ekstra tur ned og opp trapper, inn og ut av taxi, over glatte fortau. Jeg måtte betale for bildene og ta dem med. I Skottland er time med spesialist samordnet med røntgen i samme sykehus, under samme tak og på samme dag. Bildene overføres elektronisk til spesialist på minuttet.

\section{Fritt behandlingsvalg \\ og «the inverse care law»}

«Men tenk på den korte ventetiden. Man kan da ikke forvente å få alt opp i hendene!», sier norske venner når jeg roser tilbudet, men legger ut om egeninnsatsen.

Men er mitt tilbud svar på lange ventetider, eller er behovet for private utøvere et symptom på at fritt valg som løsning har spilt fallitt? Fritt valg er betinget av konkurranseutsetting, og etter det jeg har sett, stykkes tjenestene her opp i mindre enheter styrt på kontrakt og avtaler som muligens enkeltvis leverer høy kvalitet, men som helhet fremstår ineffektivt og tidkrevende. Resultatet preges av «the inverse care law» (2): Tjenestene er minst tilgjengelig for dem som trenger det mest.

Så lenge jeg kan, greier jeg meg med så lite ekstra hjelp som mulig. Men mine ressurser brukes nå på meg selv og profittmarginen til en privat aktør, ikke å bidra til en helhet som frigir muligheter til dem som er mindre heldigstilte. Og en dag blir jeg en av dem - gammel, ufør, ulønnsom - én blant de økende helseutfordringene sårbare grupper med sammensatte problemer representerer.

I Skottland har år med resultatstyrt sam- arbeid på tvers av profesjons- og organisasjonsgrenser laget en maksimum 18-ukersgaranti for henvisning til spesialisthelsetjenesten (3). Tjenestene tilbys av et mindre antall offentlige kvalitetssikrede tjenester hvor man jobber aktivt med fastleger for å sikre at henvisninger er relevante og presset på sykehussektoren reduseres. Integrerte tjenester følger sårbare pasienter opp utenfor spesialisttjenesten. Helseressurser beholdes i en offentlig pott. Systemet er ikke perfekt og knaker nå under resesjonen. Men hvis Skottland kan (4), hvorfor ikke Norge?

\section{Postskriptum - en ny runde?}

Tomånederskontrollen viste at et lite inngrep måtte til for å fjerne en pinne. «Tar ti minutter», sa kirurgen og avtalte time der og da. Så kom det et brev med beskjed om at virksomheten mistet Raskere tilbakekontrakten på nyåret, og at helseforetaket ikke godkjenner pinnefjerning for offentlige pasienter. Men jeg var henvist til en annen avdeling, i samme virksomhet, med kontrakt. Denne avdelingen sendte meg et brev med referanse til mye lovverk: «Denne diagnosen går dessverre ikke under vår avtale om offentlig refusjon for utredning/ behandling. Vi anbefaler at du tar kontakt med din fastlege.»

\section{Guro Huby \\ guro.o.huby@hiof.no}

Guro Huby (f. 1953) er ph.d. og førsteamanuensis ved Avdeling for helse og sosialfag, $\mathrm{H} ø g$ skolen i Østfold.

Forfatter har fylt ut ICMJE-skjemaet og oppgir ingen interessekonflikter.

\section{Litteratur}

1. Høie B. Sykehustalen 2016. https://regjeringen.no/ no/aktuelt/sykehustalen-2016/id2470065/ (17.2.2016)

2. Hart JT. The inverse care law. Lancet 1971: 1 405- 12 .

3. The Scottish Government. HEAT standard. http://gov.scot/About/Performance/scotPerforms/ partnerstories/NHSScotlandperformance/ 18weeksRTTStandard (17.2.2016).

4. Brandstorp H. Vil sette legers verdier i spill. Tidsskr Nor Legeforen 2016; 136: 224-6.

Mottatt 9.2. 2016, første revisjon innsendt 18.2 . 2016, godkjent 19.2. 2016. Redaktør: Ketil Slagstad Engelsk oversettelse på www.tidsskriftet.no Publisert først på nett. 